
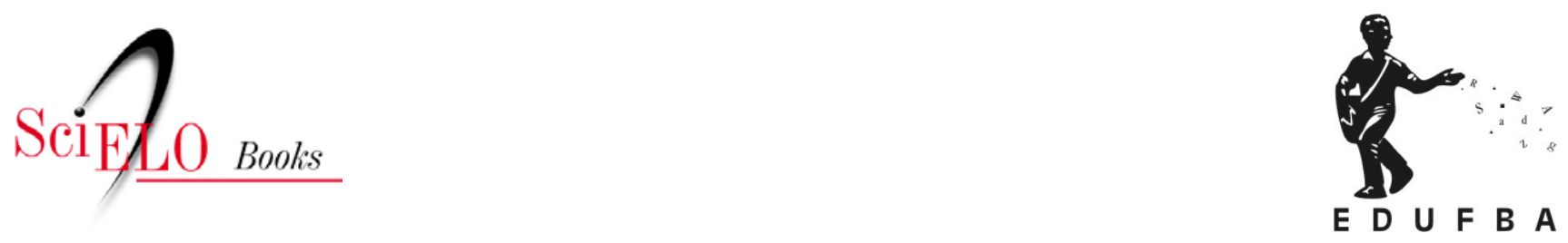

\title{
A implantação do trabalho prisional na penitenciária da Bahia (1833-1865)
}

\author{
Cláudia Moraes Trindade
}

\section{SciELO Books / SciELO Livros / SciELO Libros}

TRINDADE, C.M. A implantação do trabalho prisional na penitenciária da Bahia (1833-1865). In: COELHO, M.T.Á.D., and CARVALHO FILHO, M.J., orgs. Prisões numa abordagem interdisciplinar [online]. Salvador: EDUFBA, 2012, pp. 15-30. ISBN 978-85-232-1735-8. Available from: doi: 10.7476/9788523217358.003. Also available in ePUB from: http://books.scielo.org/id/7mkg8/epub/coelho-9788523217358.epub.

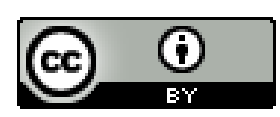

All the contents of this work, except where otherwise noted, is licensed under a Creative Commons Attribution $\underline{4.0 \text { International license. }}$

Todo o conteúdo deste trabalho, exceto quando houver ressalva, é publicado sob a licença Creative Commons Atribição 4.0.

Todo el contenido de esta obra, excepto donde se indique lo contrario, está bajo licencia de la licencia Creative Commons Reconocimento 4.0. 


\section{A implantação do trabalho prisional na penitenciária da Bahia (1833-1865) ${ }^{1^{*}}$}

Cláudia Moraes Trindade

\section{Introdução}

A partir da segunda metade do século XIX foram inauguradas as penitenciárias no Brasil, também denominadas de Casa de Correção e Casa de Prisão com Trabalho. Naquela época pouco se produzia intelectualmente sem a influência das ideias estrangeiras, as quais sofriam adaptações para a realidade local. ${ }^{2}$ Assim aconteceu com a implantação do projeto civilizatório que tomou conta do Brasil no oitocentos. Instituições foram construídas no intuito de acompanhar os padrões de controle social em voga nos países como a França, Inglaterra e Estados Unidos. No decorrer do século XIX, cemitérios, asilos, hospitais, colégios, internatos e prisões foram gradativamente fazendo parte do cenário da capital baiana ao mesmo tempo em que seus regulamentos se adaptavam a uma sociedade escravista específica como

1 * Este texto é parte de uma pesquisa mais ampla desenvolvida durante o mestrado no Programa de Pós-Graduação em História da UFBA, sob a orientação do Prof. João José Reis, a quem agradeço pelas sugestões e indicação de fontes e bibliografia. A pesquisa contou com o apoio do CNPq. O assunto tratado aqui foi apresentado, em 2008, no V Colóquio Internacional de Trabalho Forçado Africano - Brasil, 120 anos da Abolição. Agradeço aos membros da linha de pesquisa Escravidão e Invenção da Liberdade, do PPGH/UFBA, pelos comentários feitos a uma versão anterior.

2 Sobre o liberalismo, ver Marson (2002), Mattos (1990), Silva (1997, entre outros. 
era a nossa naquele período. ${ }^{3}$ Conforme sinalizou Michel Foucault, essas instituições de vigilância exerciam um poder social que visava enquadrar as pessoas no mundo capitalista. Para o autor, a atuação desse poder social esperava que "o homem transformasse seu corpo, sua existência e seu tempo em força de trabalho”. (FOUCAULT, 2003, p. 67) Essas instituições atuavam como uma ameaça para as pessoas que não atendiam aos padrões civilizatórios defendidos pelas elites locais. Para as classes mais abastadas as ruas e praças da cidade ocupadas por mendigos, escravos, pessoas doentes, abandonadas à própria sorte, era um dos empecilhos para que a Bahia alcançasse o seu espaço no mundo civilizado. A população baiana, em sua maioria, vivia na mais absoluta pobreza. Segundo Mattoso (1974), os pobres representavam cerca de 90\% dos habitantes de Salvador no século XIX. Sem contar a população escrava que era bastante significante. Em 1835, por exemplo, dos 65.500 habitantes, 42\% eram escravos. (REIS, 2003) Entretanto, a tentativa de controlar essa população foi uma tarefa árdua para as autoridades da época.

16 No início da década de 1830, as discussões sobre a reforma prisional tomaram força na Bahia e no Brasil de um modo geral. Porém, os primeiros passos desse projeto foram dados antes mesmo da independência do Brasil. Pouco tempo depois de assumir a regência, D. Pedro I assinou a Lei de 23 de maio de 1821 que visava garantir os direitos individuais contra a arbitrariedade dos juízes criminais no Brasil. Dentre outras medidas, essa lei proibia que os presos fossem conservados nas masmorras "escuras ou infectas", e sim em cadeias "arejadas e cômodas" sendo que eles não deviam sofrer "qualquer espécie de tormento”. (COELHO, 1999) Essa determinação antecedeu o que a Constituição viria reforçar em 1824. Outro acontecimento importante naquele momento foi a atuação de Cipriano Barata na Corte de Lisboa, em fevereiro de 1823, onde, entre outros projetos, apresentou um que reivindicava mudanças no aparelho prisional do Brasil. Ele que conheceu de perto as masmorras das fortalezas e as cadeias coloniais, devido às várias vezes em que foi preso, em seu pronunciamento, remeteu-se diretamente à Bahia, pedindo que fossem interditadas as prisões do forte de São Pedro e as do forte do Mar. (TRINDADE, 2007) A sua

3 Sobre essas instituições baianas oitocentistas, ver Reis (1991), Fraga Filho (1999), Rios (2006), Matta (1996), Leal (1996), Trindade (2008), Kraay (2001). 
reivindicação não foi atendida. Em 1832, Cipriano constatou de perto que a prisão da fortaleza do mar funcionava em pleno vigor. Ele era um dos presos políticos que ali estavam. (TRINDADE, 2007) Em 1824, a Constituição do Brasil determinou a construção de cadeias arejadas, limpas e com várias celas, prezando também pela separação de presos conforme a natureza de seus crimes. Proibiu as torturas e estipulou a elaboração de um Código Criminal para substituir o temido livro V das Ordenações Filipinas, que até então regia as leis criminais no Brasil.

Em 1833, a Bahia iniciou a construção da sua primeira penitenciária que foi inaugurada no ano de 1861. A instituição recebeu o nome de Casa de Prisão com Trabalho e representou para a província um importante passo no projeto da reforma prisional baiana. ${ }^{4}$ (SALLA, 1997) A instituição foi construída na periferia da cidade de Salvador, nas terras fronteiras ao Engenho da Conceição aos fundos da Capela dos Mares, na Freguesia da Nossa Senhora da Penha de França de Itapagipe. A partir de 1870, esta freguesia foi desmembrada e o local passou a pertencer à Freguesia de Nossa Senhora dos Mares. ${ }^{5}$ Foi nesta penitenciária que as autoridades baianas planejaram colocar em prática um novo conceito de punição, baseado na privação da liberdade e na reabilitação do condenado. Na época, o Brasil acompanhava uma tendência mundial de modernização das prisões, que teve início na Inglaterra e nos Estados Unidos no final do século XVIII. As execuções e as torturas em praças públicas, utilizadas para atemorizar a quem estivesse planejando novos crimes foram, gradativamente, abandonadas pelos países do Ocidente. Entrava em cena a penalidade moderna, que privava o criminoso do seu bem maior - a sua liberdade - internando-o numa instituição construída, especificamente, para recuperá-lo, que recebeu o nome de penitenciária. O funcionamento desta instituição era regido por normas que seriam aplicadas de acordo com o sistema penitenciário adotado. Esses sistemas utilizavam como método de punição e recuperação elementos como o trabalho, a religião, a disciplina, o uso de uniformes, o silêncio e, sobretudo, o isolamento.

4 O termo "casa" era usado anteriormente para designar as cadeias, como, por exemplo, Casa de Câmara e Cadeia. Em relação ao nome "casa penitenciária", Fernando Salla (1997) sugere que a palavra "Casa" deva ser entendida como era utilizada no período colonial, "especialmente para se referir a uma casa de prisão, ou seja, uma dependência, uma sala, um cômodo, no interior de uma construção".

5 Atualmente esta área é conhecida como Baixa do Fiscal e no edifício da antiga Casa de Prisão funciona o Hospital de Tratamento e Custódia do Estado da Bahia. 
Dessa forma, esperava-se criar um "novo homem" que seria devolvido à sociedade com todos os atributos necessários à convivência social, principalmente para o trabalho. ${ }^{6}$ (TRINDADE, 2007)

Dois sistemas rivais - Auburn e Pensilvânia - dividiram as opiniões dos reformadores estrangeiros e também da Bahia. O sistema de Auburn, também conhecido como silent system, consistia na prática de atividades coletivas durante o dia, no mais absoluto silêncio, e no isolamento à noite. O outro, chamado de sistema da Pensilvânia, sistema da Filadélfia, ou ainda, de sistema celular, estabelecia o isolamento do preso, dia e noite, executando trabalhos individuais, como o artesanato. Neste último caso, as celas deveriam ser especiais, isto é, mais espaçosas; adaptadas para que o preso passasse ali todo o tempo. Neste caso o custo era bem maior do que no modelo Auburniano. Em ambos os sistemas o trabalho prisional era o pivô do processo de reabilitação.

\section{O trabalho prisional e o trabalho forçado}

O Código Criminal do Império do Brasil de 1830 estabeleceu a pena de prisão com trabalho para a maioria dos crimes, desde que o infrator não fosse de condição escrava. Para este último, o Código reservou o seu artigo 60 que previa punição com açoites e, em alguns casos, galés e pena de morte. ${ }^{7}$ (FILGUEIRAS JUNIOR, 1876) O Código também determinou que a pena de prisão com trabalho deveria ser cumprida em instituições construídas, especificamente, para este fim e, enquanto as províncias não dispusessem de casas de correção, como também eram chamadas as penitenciárias no século XIX, a pena seria comutada para prisão simples. ${ }^{8}$ (FILGUEIRAS JUNIOR, 1876) Significa dizer que o indivíduo condenado à pena de prisão com trabalho não deveria executar qualquer tipo de trabalho, principalmente do lado externo da prisão. Antes da reforma prisional, o trabalho executado pelos presos estava relacionado ao trabalho forçado, como acontecia

6 Sobre a reforma prisional baiana e o processo de implantação da primeira penitenciária da Bahia. (TRINDADE, 2007) Doravante a Casa de Prisão com Trabalho poderá ser indicada pela sigla CPCT ou simplesmente denominada de penitenciária.

7 “Art. 60. Si o réo for escravo, e incorrer em pena que não seja a capital ou de galés, será condenado na de açoutes, e, depois de os soffrer, será entregue a seu senhor, que se obrigará a traze-lo com um ferro, pelo tempo e maneira que o juiz designar". (FILGUEIRAS JUNIOR, 1876)

8 Ver artigos 46 e 49 do Código Criminal do Império. (FILGUEIRAS JUNIOR, 1876) 
com os sentenciados à pena de galés. Neste caso os "galés" eram distribuídos nas obras e serviços públicos da cidade. Vale ressaltar que uma das características do antigo regime prisional era o trânsito de presos pela cidade, desempenhando serviços públicos para garantir o sustento dentro da cadeia. ${ }^{9}$ Este tipo de atividade laboral não fazia parte de nenhum projeto de reabilitação. A pena de galés era aplicada ao sentenciado, independente da sua condição jurídica, muito embora o maior número de condenados a galés fosse formado por escravos. Assim podemos dizer que o trabalho dos presos, no antigo regime prisional, estava relacionado, principalmente, com a figura do escravo, enquanto o trabalho na penitenciária estava direcionado para homens de condição livre e liberta. Carlos Eugênio Soares descreve as várias modalidades de trabalhos forçados e formas de acorrentamento a que os presos, condenados a galés, eram submetidos no Dique da Ilha de Cobras. Uma dessas formas era o libambo - quando três ou mais escravos, unidos por uma corrente, buscavam água para garantir o abastecimento da Ilha. (SOARES, 2003) Ressalto que, mesmo com a implantação das penitenciárias no Brasil, o trabalho forçado dos sentenciados a pena de galés coexistiu com o novo regime prisional enquanto durou a escravidão.

\section{O trabalho prisional em diferentes contextos}

Cada sociedade aderiu ao trabalho prisional de acordo com a sua realidade local. Enquanto o Brasil tinha uma economia escravista, países como a França e os Estados Unidos, por exemplo, viviam um contexto de industrialização. Para Catherine Duprat, referindo-se à reforma prisional na França, a implantação de oficinas de trabalho na prisão tinha lá sua complexidade, pois, entre outras dificuldades, havia o conflito de interesses econômicos com a indústria livre. O Estado contava com o investimento da iniciativa privada, e a figura do empreendedor era outro desafio, uma vez que este visava o lucro do seu investimento. Referindo-se ao empreendedor Duprat observa que "nem pedagogo, nem filantropo, melhorar o prisioneiro não é

9 No século XIX o governo só arcava com a alimentação e vestimentas dos presos pobres, ou seja, aqueles que não contavam com amigos e parentes para auxiliar no seu sustento e também que, por algum motivo, não tivessem condições de trabalhar, seja em serviços internos ou até mesmo fora da cadeia. 
assunto seu”. (DUPRAT, 1819, p. 1997) Michel Foucault informa que por volta de 1840, os operários franceses teriam reagido com greves e protestos contra as oficinas das prisões, devido ao baixo custo da mão de obra penal. Os operários livres acusavam o governo de incentivar o trabalho penal para baixar os salários. (FOUCAULT, 1997; PERROT, 2001; PESSOA, 2000; SALLA, 1994)

Os franceses Alexis de Tocqueville e Gustave de Beaumont estiveram nos Estados Unidos por volta de 1830 a fim de observar as prisões daquele país, buscando melhorias e sugestões para as penitenciárias francesas. Os Estados Unidos eram, na época, a referência mundial dos modelos penitenciários. Embora a dupla de estudiosos franceses preferisse o sistema da Filadélfia por manter o condenado no isolamento contínuo, eles reconheceram que o modelo de Auburn, que previa as oficinas de trabalho, era menos custoso. Tocqueville e Beaumont levantaram importantes considerações sobre o investimento das empresas privadas nas prisões. No relatório, fizeram críticas quanto à organização do trabalho prisional na França ressaltando a interferência desmedida do empreendedor junto aos presos. Por outro lado elogiaram o modelo de organização do trabalho prisional nas prisões norte americanas uma vez que as empresas privadas não tinham nenhum poder de interferência junto aos presos. (SALLA, 1994)

Para David Rothman, que estudou a reforma das prisões nos Estados Unidos, havia semelhanças entre as novas instituições prisionais e as novas fábricas que estavam mudando a economia dos Estados Unidos. "Na aparência e na rotina, a prisão e a fábrica eram parecidas. Ambas enfatizavam a regularidade e a pontualidade. Certamente que a partir dessa observação, alguns historiadores relacionaram as origens das prisões com a nova ordem econômica”. (ROTHMAN, 1995, p. 123) Vimos então que a discussão do trabalho prisional, em países da Europa e nos Estados Unidos, estava atrelada ao processo de industrialização. Na Bahia, o trabalho estava relacionado a uma economia que se encontrava num processo de transição da mão de obra escrava para a livre.

Na Bahia, em 1846, quando as discussões sobre a reforma prisional atingiram o auge, o então presidente da província, Francisco José de Souza Soares de Andréa, nomeou uma comissão composta por bacharéis, médicos e engenheiros para analisar a implantação da Casa 
de Prisão com Trabalho, que se encontrava em construção. ${ }^{10}$ (SYSTEMA PENITENCIÁRIO, 1868) Esse grupo, influenciado por reformadores franceses, entre eles Tocqueville e Beaumont, defendeu que a Bahia não deveria adotar o sistema das oficinas de ofício, ou seja, o chamado sistema de Auburn. Para eles o sistema da Filadélfia ou Pensilvânia, embora mais oneroso, se adaptaria melhor às necessidades locais, pois os presos executariam trabalhos individuais em suas celas. Temia-se que as atividades coletivas poderiam facilitar a corrupção e outros "vícios" entre os criminosos. É bem provável que nossos reformadores estavam a seguir a preferência da França que, nesta época, já havia abandonado o sistema de Auburn e adotado o sistema da Pensilvânia para, mais tarde, em meados da década de 1850 optar pela pena de deportação para a maioria das condenações. (PERROT, 2001) No entanto, a "ilustrada" comissão baiana tinha outras preocupações, dentre elas a de poupar presos políticos do trabalho nas oficinas, o que significa que estava preocupada com as pessoas pertencentes às camadas mais abastadas.

Os nossos presos tinham já profissões a que soltos podem voltar; outros viviam do trabalho do campo que não há utilidade em ensinar-lhes a desprezar; os demais, porque a posição social lhes proíbe as artes mecânicas, ou não tem ofício, ou deles não precisam quando livres: logo para a maior parte nem só lhes não é de utilidade, como até poderia prejudicar-lhes, o mister que dali trouxessem aprendido. (PERROT, 2001, p. 18)

Com esse argumento a comissão sugeriu que a lei fosse revista, a fim de conceder privilégios aos presos políticos, garantindo que "todas as vezes que uma condenação levasse os réus desses crimes a uma penitenciária, o trabalho não lhes fosse obrigatório”. A alegação era que os trabalhos manuais "humilham os instintos literários". (PERROT, 2001, p. 52) A revisão de lei não foi atendida. O temor de que algum de seus pares pudessem terminar numa das oficinas da penitenciária deu ao discurso da comissão um tom que parecia contrário às idéias em voga na época, com relação à instrumentalização para o trabalho

10 A comissão foi composta por pessoas ilustres como Cassemiro de Sena Madureira, Luiz Maria Alves Falcão Moniz Barretto, Eduardo Ferreira França, João Baptista dos Anjos, Francisco Primo de Souza Aguiar, João Baptista Ferrari e João José Barboza de Oliveira. Este último, pai do jurista Rui Barboza, também atuou como Relator do relatório do Systema penitenciário que foi entregue, após um ano de estudos, ao governo provincial. 
da emergente população livre e pobre, discussão esta que antecede a da reforma prisional no Brasil. Conforme Walter Fraga, "ao mesmo tempo em que se anunciava a crise do escravismo pela inevitabilidade do declínio da população escrava, a população livre se multiplicava rapidamente. Logo ficou claro que era desta que dependeria o futuro da produção". (FRAGA FILHO, 1999, p. 170) Muitos políticos acreditavam que o trabalho era um elemento regenerador capaz de afastar os vícios dos criminosos. Em 1842, por exemplo, o presidente da província, Joaquim José Pinheiro de Vasconcellos, escreveu sobre os efeitos do trabalho na população livre:

O tempo empregado no trabalho faltaria para o crime, e mesmo para o vício; e as horas destinadas para o descanso seriam empregadas em calcular as maiores vantagens, que se pudesse tirar do fruto do trabalho, por conseqüência teríamos todo o tempo empregado utilmente. É necessário convencer aos homens pobres, que somente o trabalho os pode fazer menos dependentes dos ricos, e dar-lhes em sentimento mais elevado de sua dignidade de homens livres. (VASCONCELLOS, 1842, p. 5)

No que se refere ao trabalho prisional, a Inglaterra, os Estados Unidos e a França incorporaram experiências das workhouses inglesas desde o século XVI, onde os pobres eram recolhidos a fim de serem disciplinados para o trabalho. No caso brasileiro, as elites incorporaram o trabalho prisional às discussões em voga, desde o início do século XIX, que visavam instrumentalizar a população pobre para o trabalho. (MCGOWEN, 1995) Em 1830, por exemplo, o governo baiano tomou providências para reservar parte do mercado de trabalho para a mão de obra livre, proibindo os escravos de executarem certas atividades. (FRAGA FILHO, 1999, p. 26) Entretanto, alguns trabalhos manuais eram vistos com preconceito, principalmente por estarem relacionados aos negros e aos escravos em particular. Mesmo assim, acredito que o trabalho prisional não foi contraditório ou tenha dificultado a implantação das idéias penitenciárias na Bahia. Essa minha interpretação contradiz a opinião de Patrícia Aufderheide. Para a autora, "uma grande ambigüidade rondava o papel da instituição penal, que enfatizava o valor do trabalho numa sociedade onde o trabalho manual era a marca da pobreza, discriminação racial e da escravidão”. (AUFDERHEIDE, 1976) Proponho que a discussão do trabalho prisional deva ser relacionada à 
trajetória da sociedade brasileira rumo ao trabalho livre e não analisá-la à luz da escravidão, o que pode nos levar a uma visão reducionista.

Desde o fim do século XVIII, Salvador já contava com a Casa Pia Colégio de Órfãos de São Joaquim, que foi a principal formadora de trabalhadores assalariados da cidade. (MATTA, 1999) Essa instituição privilegiava a admissão de menores brancos e mulatos, excluindo os negros, dificultando que estes ingressassem no mercado de trabalho livre que despontava na cidade de Salvador no século XIX. (MATTA, 1999) De qualquer forma, a população livre se sentia constrangida em executar certos ofícios que a equiparassem à condição de escravos. Porém, não era qualquer trabalho que era recusado. Segundo Matta, a mão de obra qualificada, no século XIX, era escassa por exigir "trabalhadores treinados e até alfabetizados, portanto, muito difícil de se achar entre os escravos". (MATTA, 1999, p. 204) Para Matta, os ofícios especializados como o de carpinteiro, marceneiro, ferreiro, alfaiate, sapateiro, caldeireiro e funileiro eram mais ocupados por pessoas livres do que por escravos os quais, geralmente, eram designados para "ofícios mais pesados da construção civil e aos menos especializados" como pescador, calafate, carvoeiro, pedreiro, servente, etc. Alguns ofícios eram mais comuns do que outros como, por exemplo, o de sapateiro, que exigia menos estudos. Já o ofício de marceneiro, especializado na fabricação de móveis, "era mais valorizado do que o de carpinteiro que trabalhava com madeira, porém de um modo mais rústico, fornecendo material destinado à construção civil”. (MATTA, 1999, p. 171) Vale destacar que a primeira oficina da penitenciária a entrar em atividade foi a de marcenaria.

Com a inauguração da Casa de Prisão com Trabalho, em 1861, prevaleceu a idéia das oficinas de ofício, contrariando a orientação da comissão constituída em 1846. Infelizmente não localizei a documentação que encaminhou para esta tomada de decisão contrária. Em 1865, finalmente foram inauguradas as oficinas de marceneiro, alfaiate, sapateiro e carapina. O regulamento da Casa de Prisão com Trabalho não mencionou o sistema penitenciário adotado, mas pode-se interpretar que se tratou do sistema de Auburn modificado. Podemos dizer que foi a adaptação da penitenciária à realidade baiana.

Em setembro de 1865, após visitar a Casa de Prisão com Trabalho em companhia do presidente da província, o chefe de polícia autorizou 
o início das atividades das oficinas de trabalho. ${ }^{11}$ Justificou sua decisão devido às reclamações dos presos de estarem "encerrados dia e noite em uma cela", com "falta de ar e exercício". ${ }^{12}$ A solução encontrada pelo chefe de polícia foi empregar nas oficinas os presos que conhecessem algum ofício; e o restante nas obras de aterro do pátio, em turmas de vinte ou trinta por dia. Neste caso foi acertado um "salário módico de duzentos a trezentos réis diários”, que seriam pagos pelo arrematador da obra. O chefe de polícia também decidiu que os trabalhadores das oficinas e das obras receberiam metade dos seus salários, enquanto o restante seria guardado em "depósito ou em uma caixa” e, posteriormente, entregue ao preso depois de cumprida a sentença; ou à família, "quando a pena de prisão não fosse temporária, ou o preso falecesse". ${ }^{13}$

No dia 23 de outubro de 1865, foram feitos os primeiros ensaios na oficina de marceneiro com os presos José Raimundo, Antonio Manuel do Nascimento Silva Monte Negro, Manoel Constantino Cardoso e Avelino José Jerônimo. Esses presos operários, como se auto denominavam, tinham a tarefa de "fazer os móveis, precisos para montar as outras oficinas". ${ }^{14}$ Cinco dias depois, Avelino foi substituído por outro preso, o escravo Cassiano. O motivo do afastamento teria sido o seu "mau comportamento". ${ }^{15}$ Este poderia ser os primeiros sinais de resistência ao trabalho prisional. Quanto ao escravo Cassiano, sabemos que não era sentenciado à prisão com trabalho, pois o Código Criminal era bem claro quanto à proibição de escravos cumprirem este tipo de pena. A sua presença na oficina é mais um indício da adaptação do sistema penitenciário à realidade prisional da Bahia. Apesar de serem poucos os escravos na penitenciária, eles existiam e eram, geralmente, pessoas condenadas à pena de morte que aguardavam pedido de graça feito do imperador ou condenados às galés. Os mestres de oficio eram escolhidos entre os profissionais da cidade e o primeiro a assumir a oficina de marcenaria foi José Polibio da Rocha que permaneceu neste

11 Chefe de polícia para o presidente da província, (04/09/1865), APEBa, Cadeias, 1836-1868, maço 3082. 12 Chefe de polícia para o presidente da província, (04/09/1865), APEBa, Cadeias, 1836-1868, maço 3082 13 Chefe de polícia para o presidente da província, (04/09/1865), APEBa, Cadeias, 1836-1868, maço 3082. Arrematantes eram os particulares que firmavam contrato de serviços com a Casa de Prisão com Trabalho.

14 Chefe de polícia para o administrador da CPCT, (23/10/1865), APEBa, Casa de Prisão, 1865, maço 5926.

15 Chefe de polícia para o administrador da CPCT, (28/10/1865), APEBa, Casa de Prisão, 1865, maço 5926. 
cargo por muitos anos. Em 1865, o valor da sua diária de trabalho era de 1200 réis mais a $3^{\mathrm{a}}$ parte do produto manufaturado. ${ }^{16} \mathrm{Um}$ mês depois, chegaram os primeiros presos aprendizes, Bernardino Gil d'Andrade e João Mathias dos Santos. Em seguida, começaram a funcionar as oficinas de alfaiate, sapateiro e carapina. Foram nomeados como mestres, respectivamente, Augusto do Amaral, o ex-guarda da Casa de Prisão com Trabalho Braz Diogo das Chagas e Rufino Marques Carvalho. ${ }^{17} \mathrm{Na}$ oficina de sapateiro foram empregados dez presos. ${ }^{18} \mathrm{~A}$ escolha da especialidade das oficinas estava relacionada aos produtos necessários à infra-estrutura da penitenciária. O artigo 110 do regulamento previa a existência de "oficinas convenientes, preferindo-se as que menos complicadas forem e maior extração acharem os seus produtos”. (CASA DE PRISÃO DA BAHIA, 1863, art. 110) No Rio de Janeiro, a escolha das oficinas também foi ditada pela necessidade dos produtos. Segundo o Diretor da penitenciária da Corte, Miranda Falcão, os presos deveriam "confeccionar aquilo de que o estabelecimento tem necessidade”. (PESSOA, 2000, p. 90)

O regulamento da Casa de Prisão com Trabalho determinou horário rigoroso para o funcionamento das oficinas. No verão os trabalhos deveriam começar às 05h30min e, no inverno, às 06h30min da manhã com intervalo para o almoço e jantar, sendo encerrado o expediente às 05h30min no verão e às 06h30min da tarde no inverno. Antes do início dos trabalhos era feita a oração matinal e, em seguida, os chefes das oficinas conduziam as turmas para as respectivas oficinas. (PESSOA, 2000) A rotina do trabalho era orientada pelo toque de uma sineta onde o número de badaladas indicava as atividades. ${ }^{19}$ Ao término dos trabalhos, os presos tinham que arrumar as ferramentas. Para se ausentar das oficinas, por qualquer necessidade, o preso teria que pedir autorização a um guarda. Durante o trabalho, os presos só podiam se comunicar caso houvesse necessidade de pegar alguma ferramenta ou, se aquele que estivesse aprendendo um ofício precisasse falar com o

16 Chefe de polícia para o administrador da CPCT, (03/11/1865), APEBa, Casa de Prisão, 1865, maço 5926.

17 Ofícios do chefe de polícia para o administrador, (27/10/1865), (07/11/1865), (22/11/1865), APEBa, Casa de Prisão, 1865, maço 5926.

18 Chefe de polícia para o administrador, (22/11/1865), APEBa, Polícia, Casa de Prisão, 1865, maço 5926. 19 “Aditamento ao Regulamento interno das oficinas da Casa de Prisão com Trabalho", APEBa, Relação de Presos, 1862-1867, maço 6272 . 
mestre, isso deveria ser feito em "voz baixa e respeitosamente". Quando não estivessem próximo ao mestre, para falar com ele, deveriam bater palmas uma vez e aguardar que este se aproximasse. (CASA DE PRISÃO COM TRABALHO DA BAHIA, 1863) Tipo de exigência que visava a subordinação e o controle dos presos operários. A documentação informa que esse rigor disciplinar acontecia na prática. Aliás, é importante destacar que a prisão baiana oitocentista era um lugar de ordem e de desordem a depender das parcerias, das negociações ou da falta destas. (TRINDADE, 2009)

\section{Concluindo}

Na Casa de Prisão com Trabalho da Bahia, a prática não correspondeu às expectativas das autoridades baianas. No final da década de 1870, uma série de escândalos envolvendo corrupção de funcionários e descontrole dos presos trouxe à tona irregularidades no funcionamento das oficinas. O administrador Manoel Diniz Villas Boas, após ser exonerado acusado de desviar os dinheiros das oficinas, tornou público, em 1867, que o trabalho prisional era facultativo aos presos, quando deveria ser obrigatório, e os mestres das oficinas não cumpriam horários. Estes últimos seriam coniventes com a traficância interna, promovida por funcionários da guarda e da enfermaria. Muitos presos só eram recolhidos à noite e, durante o dia, ficavam na rua jogando ou em companhia de mulheres. Os sentenciados se

constituíam correspondentes do Alabama, onde faziam inserir insultos e os maiores sarcasmos contra a administração e mais empregados do Estabelecimento. Condenados, enfim, que se dirigiam por meio de representações aos Ministros da Coroa, queixando-se do Ajudante do mesmo estabelecimento, e imputando-lhe fatos os mais torpes e horrorosos". Villas Boas descreveu o pátio da penitenciária como sendo uma verdadeira "quitanda, onde tinha franco ingresso um sem número de pretas com tabuleiros e caixinhas. (VILLASBOAS, 1868, p. 6)

As denúncias se seguiram, reforçando ainda mais que a comunidade prisional estava longe de ser um espaço de calmaria e dominação como os reformadores e as autoridades provinciais esperavam que fosse. 
A implantação do trabalho prisional não se resumia a ensinar um ofício ao condenado. Esperava-se que o trabalho fosse um instrumento disciplinador para condicionar o preso a receber ordens e cumpri-las tal como ele, mais tarde, deveria se comportar na vida em sociedade. O aproveitamento do tempo dos presos, através do trabalho, anunciou uma nova etapa na história da prisão na Bahia. Tentava-se combater o antigo modelo de aprisionamento, que castigava sem incluir um projeto de reabilitação. Porém, não podemos perder de vista que a reforma prisional na Bahia, e no Brasil de um modo geral, não significou uma ruptura das práticas de punição coloniais, regidas pelo Livro V das Ordenações Filipinas. Junto com o projeto de recuperar o condenado, as leis criminais do Império do Brasil mantiveram penas contrárias a esse princípio, como a de morte, galés perpétua e desterro, todas elas inerentes ao antigo regime prisional. Vale frisar que essa continuidade não foi exclusividade do Brasil. O mesmo ocorreu em países considerados referência da reforma prisional tal como a Inglaterra, os Estados Unidos e a França. Quanto aos modelos estrangeiros - Auburn e Pensilvânia --, a instituição não seguiu, na íntegra, a nenhum deles. Diria que, no máximo, o sistema de Auburn foi adaptado à realidade prisional da Bahia, para não negar totalmente a influência do modelo norte americano. Por fim, acredito que não devemos julgar se a experiência da penitenciária na Bahia fracassou ou não, como alguns autores insistem em fazê-lo. Entendo que ela se adaptou aos interesses locais, como ocorreu com todas as outras idéias e reformas "liberais" no Brasil oitocentista.

\section{Referências}

AGUIRRE, Carlos. The Criminals of Lima and Their Worlds: The Prison Experience, 1850-1935. Durham: Duke University Press, 2005.

AUFDERHEIDE, Patrícia. Order and Violence: Social Deviance and Social Control in Brazil, 1780-1840. 1976. Tese (Doutorado) - University of Minnesota, Minnesota, 1976.

BEAUMONT Gustave de, TOCQUEVILLE. Du système pénitentiaire aux États-Unis et de son application en France, suivi d'un appendice sur les colonies pénales et de notes statistiques. 2. éd.. Paris: Impr. de H. Fournier, 1833. Paris: C. Gosselin, 1836. v. 2. 
BRASIL. COLLEÇÃO das Leis do Império do Brazil. Rio de Janeiro: Typografia Nacional, 1878.

CASA DE PRISÃO COM TRABALHO DA BAHIA. Regulamento da casa de prisão com trabalho da Bahia. Bahia: Typ. Poggetti - de Tourinho; Dias \& C, 1863; Bahia: Typ. Poggetti, 1863. Aprovado pelo presidente da província o conselheiro Antonio Coelho de Sá e Albuquerque em 14 de outubro de 1863

COELHO, Edmundo Campos. As profissões Imperiais: medicina, engenharia e advocacia no Rio de Janeiro 1822-1930. Rio de Janeiro: Record, 1999. p. 155, 157

FILGUEIRAS JUNIOR, Araujo. Código Criminal do Império do Brazil Annotado. Rio de Janeiro: Eduardo \& Henrique Laemmert, 1876.

FRAGA FILHO, Walter. Mendigos, moleques e vadios na Bahia do século XIX. Salvador: EDUFBA, 1999.

FOUCAUT, Michel. Vigiar e punir: história da violência nas prisões. 5. ed. Petrópolis: Vozes, 1987.

FOUCAULT, Michel, Prisões e revoltas nas prisões, In: MOTA, Manoel 28 Barros da (Org). Michel Foucault, estratégia, poder-saber. Rio de Janeiro: Forense Universitária, 2003, p. 67.

DUPRAT, Catherine. Punir e curar - em 1819, a prisão dos filantropos. Revista de História, v.7, n.14, p. 7-58, 1997.

LEAL, Maria das Graças de Andrade. A arte de ter um ofício: Liceu de Artes e Ofícios da Bahia (1872-1996). Salvador: Fundação Odebrecht / Liceu de Artes e Ofícios da Bahia, 1996.

LUCAS, Charles. De la réforme des prisons, ou de la théorie de l'emprisonnement, de ses principes, de ses moyens et de ses conditions pratiques. Paris: E. Legrand et J. Bergounioux, 1836-1838. v. 3

KRAAY, Hendrik. Race, State, and Armed Forces in Independence-era Brazil: Bahia, 1790's-1840's, Stanford: Stanford University Press, 2001.

MARSON, Izabel Andrade. Liberalismo versus escravidão: reflexões sobre uma relação contraditória. História e Perspectivas, v. 24, p. 39-50, 2002.

MATTA, Alfredo Eurico Rodrigues. Casa Pia Colégio de Órfãos de São Joaquim: de recolhido a assalariado. 1996. 228 f. Dissertação (Mestrado em História) - Universidade Federal da Bahia. 1996.

MATTOS, Ilmar Rohloff de. O Tempo Saquarema: a formação do Estado Imperial. São Paulo: Hucitec, 1990. 
MATTOSO, Kátia M. de Queirós. Bahia: a cidade do Salvador e seu mercado no século XIX. São Paulo: Hucitec, 1978.

MCGOWEN, Randall. The Well-Ordered Prison: England, 1780-1865. In MORRIS, Norval; ROTHMAN, David J. (Org.) The Oxford History of the Prison. New York: Oxford University Press, 1995. p.79-109.

PERROT, Michelle. Os excluídos da história: operários mulheres e prisioneiros. 3. ed. São Paulo: Paz e Terra, 2001.

PESSOA, Gláucia Tomaz de Aquino. Trabalho e resistência na penitenciária da Corte 1850-1876. Dissertação (Mestrado em História) Universidade Federal Fluminense, 2000.

ROTHMAN, David J. Perfecting the Prison: Unides States, 1789-1865. In: MORRIS, Norval;ROTHMAN, David J. (Org.), The Oxford History of the Prison. New York: Oxford University Press, 1995.p. 100-116.

REIS, João José. Rebelião escrava no Brasil: a história do levante dos Malês em 1835. Edição Revista e Ampliada. São Paulo: Companhia das Letras, 2003.

RIOS, Venétia Durando Braga. O Asylo de São João de Deus: as faces da loucura. 2006. Tese (Doutorado em História) - Pontifícia Universidade Católica de São Paulo, São Paulo, 2006.

SALLA, Fernando. Os escritos de Alexis de Tocqueville e Gustave de Beaumont sobre a prisão: o problema da participação dos negócios privados. Revista Plural, v. 1, p. 1-16, 1994.

. O Encarceramento de São Paulo: das enxovias à Penitenciária do Estado. 1997. 286 f. Tese (Doutorado em Sociologia) - Departamento de Sociologia da Faculdade de Filosofia, Letras e Ciências Humanas, Universidade de São Paulo, São Paulo, 1997.

. As prisões de São Paulo: 1822-1940. São Paulo: Anablume, 1999.

SILVA, Mozart Linhares da. Do império da lei às grades da cidade, Porto Alegre: EDIPUCRS, 1997.

SOARES, Carlos Eugênio Líbano. A Capoeira escrava e outras tradições rebeldes no Rio de Janeiro, 1808-1850. Campinas: Editora da Unicamp, 2003.

SYSTEMA PENITENCIÁRIO. Bahia: Typographia de Galdino Joze Bizerra, e Companhia, 1847. Relatório. Feito em nome da commissão encarregada, pelo Presidente da Provincia, de examinar as questões relativas à Casa de Prisão com Trabalho, da Bahia. 
TRINDADE, Cláudia Moraes. A Casa de Prisão com Trabalho da Bahia, 1833-1865. 2007. 172 f. Dissertação(Mestrado em História Social) Programa de Pós-Graduação em História Social, Universidade Federal da Bahia, Salvador, 2007.

. A reforma prisional na Bahia oitocentista. Revista de História, n158, p. 157-198, 2008.

. Para além da ordem: o cotidiano prisional da Bahia oitocentista a partir da correspondência de presos. Revista História/São Paulo. Dossiê: História, Direito e Justiça. v. 28, n. 2, 2009. (no prelo).

VASCONCELLOS, Joaquim. Fala que recitou o presidente da província da Bahia. [2 fevereiro 1842],Typ J. A. Portella e Companhia. p. 5.

VILLASBOAS, Manoel Diniz [Carta] 12 fev. 1868, Bahia [para] Presidência da Província da Bahia, Bahia: Typographia Constitucional de França Guerra, 1868, f. 5-6. Resposta apresentada pelo ex-administrador da Casa de Prisão com Trabalho da província da Bahia, tenente-coronel Manoel Diniz Villasboas, no processo de responsabilidade a que foi submentido por acto da presidencia da mesma província. 